\title{
PENGARUH LIMBAH ABU PEMBAKARAN BIOMASSA KELAPA SAWIT TERHADAP SIFAT-SIFAT FISIKA DAN MEKANIK HIGH IMPACT POLYSTYRENE
}

\author{
Fadhilla Asyri ${ }^{1{ }^{*}}$, Kartini Noor Hafni ${ }^{1)}$, A. Haris Simamora ${ }^{2)}$ \\ ${ }^{1)}$ Departemen Teknik Kimia, Fakultas Teknik, Universitas Sumatera Utara, \\ Jl. Almamater Kampus USU Medan 20155, Indonesia \\ 2) Magister Teknik Kimia, Fakultas Teknik, Universitas Sumatera Utara, \\ Jl. Almamater Kampus USU Medan 20155, Indonesia \\ *Email: fadhillaasyri@gmail.com
}

\begin{abstract}
Abstrak
Penelitian ini bertujuan untuk mengetahui pengaruh abu pembakaran biomassa kelapa sawit atau palm oil fuel ash (POFA) terhadap sifat-sifat fisika dan mekanik komposit high impact polystyrene (HIPS) yang dihasilkan. Metodologi penelitian meliputi, treatment POFA (penghidrasian POFA), pencampuran menggunakan tumbler dan ekstruder, pencetakan spesimen komposit, dan pengujian. Variabel yang digunakan adalah perbandingan berat HIPS dengan POFA berukuran lolos 140 mesh dengan variasi 95/5; 92,5/7,5; 90/10. Pengujian yang dilakukan terhadap komposit adalah Fourier Transform Infrared Spectroscope (FTIR), kadar abu, specific gravity, kekuatan tarik (tensile strength), pemanjangan pada saat putus (elongation at break), kekuatan bentur (impact strength), kekerasan (hardness), dan Scanning Electron Microscopy (SEM). Dari hasil karakterisasi FTIR diketahui terbentuknya gugus $\mathrm{OH}$ yang diduga adalah Si-OH atau Si-hidrat. Hasil pengujian sifat-sifat fisika dan mekanik komposit menunjukkan bahwa bertambahnya komposisi pengisi dalam komposit HIPS berpengisi abu yang telah ditreatment hingga rasio komposisi 90/10, mengakibatkan specific gravitynya cenderung mengalami peningkatan hingga 7,2\% dari semula, kekuatan tarik tidak mengalami perubahan yang signifikan yaitu sebesar $28,4 \mathrm{MPa}$, sifat pemanjangan pada saat putus (elongation at break) mengalami penurunan sebesar 2,7\%, kekuatan bentur cenderung menurun menjadi 3,183 KJ/m2, dan sifat kekerasan (hardness rockwell) cenderung mengalami peningkatan menjadi 110,5, serta pada uji SEM terlihat perubahan struktur pada POFA yang telah ditreatment dan terjadi interkalasi POFA pada matriks.
\end{abstract}

Kata Kunci : hidrasi POFA, HIPS, komposit HIPS - POFA, Si-hidrat.

\begin{abstract}
This study aims was to determine the effect of palm oil fuel ash (POFA) composite as filler on the physical and mechanical properties of high impact polystyrene (HIPS) composites. The research methodology included preparation of raw materials, treatment POFA (hydration process of POFA), mixing using tumbler and then extruder, molding composite specimens, and testing. The variables used were weight ratio of HIPS with 140 mesh POFA at 95/5; 92.5/7.5; 90/10. The composites were tested by Fourier Transform Infrared (FTIR), ash content, specific gravity, tensile strength, elongation at break, impact strength, hardness test, and Scanning Electron Microscopy (SEM). The results of FTIR characterization shows the formation of $-\mathrm{OH}$ bonding that was suspected as $\mathrm{Si-OH}$ or $\mathrm{Si}$ hydrat. Results of physical and mechanical properties of the composites shows that increase of the filler composition in HIPS-POFA composites until the ratio of 90/10, increase the specific gravity to $7.2 \%$ of the original, tensile strength did not change significantly to $28.4 \mathrm{MPa}$, elongation at break decreased to $2.7 \%$, impact strength decreased to $3.183 \mathrm{KJ} / \mathrm{m} 2$, and the hardness increased to 110.5, and Scanning Electron Microscopy (SEM) test show the transformation of POFA structure on treated POFA and intercalation between the matrix and POFA.
\end{abstract}

Key words: POFA hydration, HIPS, composite HIPS-POFA, Si-hydrat.

\section{Pendahuluan}

Kelapa sawit merupakan salah satu komoditi yang mengalami pertumbuhan sangat pesat. Indonesia memiliki potensi besar untuk memanfaatkan produk samping sawit sebagi sumber energi terbarukan. Cangkang sawit adalah limbah padat hasil pengelolaan kelapa sawit dapat menjadi salah satu potensi biomassa yang dapat menghasilkan energi [2].

Abu pembakaran biomassa kelapa sawit atau palm oil fuel ash (POFA) merupakan salah satu biomassa sektor pertanian dalam jumlah berlimpah, yang mana dapat diperoleh tanpa biaya maupun berbiaya rendah, dapat diperbaharui dan mempunyai performa yang bagus pada kondisi panas yang tinggi [4] Sebelumnya POFA hanya dibuang ke tanah kosong disekeliling pabrik kelapa sawit (PKS), dan menyebabkan masalah lingkungan dan resiko kesehatan. Oleh karena itu ditemukan solusi dalam beberapa studi untuk menggunakan POFA sebagai filler material [5]. Pemanfaatan abu pembakaran biomassa kelapa sawit sebagai pengisi dalam pembuatan komposit polimer 
mempunyai nilai yang signifikan untuk memotong konsumsi dari matriks dan bahan pengikat dari material komposit [4].

Adapun kandungan utama dari POFA seperti tampak pada Tabel 1.

Tabel 1. Kandungan Senyawa Kimia pada POFA [3]

\begin{tabular}{|l|c|}
\hline \multicolumn{1}{|c|}{ Kandungan Kimia } & POFA (\%) \\
\hline Silicon dioxide $\left(\mathrm{SiO}_{2}\right)$ & 66,91 \\
\hline Aluminium oxide $\left(\mathrm{Al}_{2} \mathrm{O}_{3}\right)$ & 6,44 \\
\hline Feric Oxide $\left(\mathrm{Fe}_{2} \mathrm{O}_{3}\right)$ & 5,72 \\
\hline Calcium oxide $(\mathrm{CaO})$ & 5,56 \\
\hline Magnesium Oxide $(\mathrm{MgO})$ & 3,13 \\
\hline Sodium oxide $\left(\mathrm{Na}_{2} \mathrm{O}\right)$ & 0,19 \\
\hline Potassium oxide $\left(\mathrm{K}_{2} \mathrm{O}\right)$ & 5,20 \\
\hline Sulfur oxide $\left(\mathrm{SO}_{3}\right)$ & 0,33 \\
\hline Phosphorus oxide $\left(\mathrm{P}_{2} \mathrm{O}_{2}\right)$ & 3,73 \\
\hline LOI & 23 \\
\hline
\end{tabular}

Polistirena adalah polimer termoplastik yang berwujud kristal yang mempunyai banyak kelebihan. Namun, polistirena ini mempunyai beberapa kelemahan, yaitu rapuh dan melunak di bawah suhu $100^{\circ} \mathrm{C}$. Karena itu, untuk menutupi kelemahan ini, diproduksi High Impact Poliystyrene (HIPS) yang mempunyai daya tahan yang lebih baik dibandingkan dengan polistirena kristal [3]. Oleh karena penambahan abu pembakaran biomassa kelapa sawit ke dalam komposit dapat mengubah sifat fisik komposit tersebut, maka peneliti merasa perlu melakukan penelitian untuk mengetahui pengaruh penambahan abu pembakaran biomassa kelapa sawit ke dalam HIPS terhadap sifat-sifat fisik komposit yang dihasilkan.

Dalam penelitian ini yang menjadi permasalahan adalah bagaimana pengaruh abu pembakaran biomassa kelapa sawit terhadap sifat-sifat fisika dan mekanik dari komposit HIPS dengan memvariasikan komposisi POFA sebagai pengisi dan HIPS sebagai matriks. Penelitian ini bertujuan untuk mengetahui pengaruh perbandingan komposisi abu pembakaran biomassa kelapa sawit terhadap sifat-sifat fisika dan mekanik komposit HIPSPOFA yang dihasilkan.

\section{Teori}

Polistirena adalah monomer, sebuah hidrokarbon cair yang dibuat secara komersial dari minyak bumi. Pada suhu ruangan, polistirena biasanya bersifat padat, dan mencair pada suhu yang lebih tinggi. Polistirena padat murni adalah sebuah plastik tak berwarna, keras dengan fleksibilitas yang terbatas. Penambahan karet pada saat polimerisasi dapat meningkatkan fleksibilitas dan ketahanan kejut. Polistirena jenis ini dikenal dengan nama High Impact Polystyrene (HIPS) [8]. HIPS ini bersifat tidak tembus cahaya, lebih keras dan lebih mudah dalam pembuatannya dibandingkan dengan produk polimer thermoplastik lainnya [3].

HIPS dapat digabungkan dengan dirinya sendiri atau material lainnya melalui adhesif atau larutan pengikat. Pelarut yang umum digunakan untuk melarutkan semen dan kemampuan polimerisasi semen akan dengan mudah menggabungkan lembaran HIPS [10]. HIPS dapat diproses dengan berbagai teknik konvensional yang biasa digunakan untuk memproses bahan termoplastik pada umumnya, yaitu dengan menggunakan injection molding ataupun dengan ekstruder. Pada injection molding, temperatur proses disarankan sekitar $180-280^{\circ} \mathrm{C}$. Umumnya, temperatur cetakan (mold) sebaiknya berada diantara 30 dan $50^{\circ} \mathrm{C}$. Untuk tingkat viskositas yang tinggi, bahan cocok diproses menggunakan ekstruder. Temperatur proses yang umum digunakan untuk memproses HIPS pada ekstruder berkisar 180$220^{\circ} \mathrm{C}[6]$.

Penambahan bahan pendispersi berfungsi sebagai pelunak atau pemlastis matriks polimer juga dapat menurunkan temperatur proses. Pelunak atau pemlastis merupakan bahan yang ditambahkan kedalam bahan polimer sehingga molekul pemlastis akan berada diatara rantai polimer yang mempengaruhi mobilitas rantai dan menaikkan plastisitas bahan [9].

Modifikasi kimia dengan perlakuan alkali dilakukan untuk meningkatkan adhesi antara permukaan partikel dengan matriks polimer yang diharapkan akan berpotensi menghasilkan ikatan yang baik. Adanya perlakuan alkali pada material akan menghilangkan sejumlah lignin, lilin dan minyak serta zat pengotor pada permukaan material, sehingga terjadi depolimerisasi pada material [1], dan juga bertujuan untuk membersihkan permukaan abu dan pori-porinya, sehingga interaksi antara matriks dapat berlangsung dengan baik melalui ikatan hidrat yang terbentuk pada POFA.

\section{Metodologi Penelitian}

HIPS Styron 438 disuplai dari Styron LLC dan POFA diperoleh dari salah satu PKS di daerah Sumatera Utara. POFA digiling di dalam ball mill untuk menyeragamkan dan memperkecil ukuran partikel. Setelah digiling kemudian POFA diayak dengan menggunakan ayakan 140 mesh. Hasil ayakan dimasukkan kedalam larutan $\mathrm{NaOH}$ 1 M sambil diaduk perlahan sampai tercapai temperatur ruang. Campuran POFA dengan $\mathrm{NaOH}$ disaring oven dengan suhu $100^{\circ} \mathrm{C}$ hingga kering. Gerus endapan kering tersebut dan digiling kembali di dalam ballmil.

HIPS dan air yang berfungsi sebagai wetting agent sebanyak $1 \%$ dari berat HIPS 
dicampur ke dalam "tumbler" selama 5 menit dan kemudian ditambahkan POFA treatment untuk varian $(5 ; 7,5$, dan $10 \%$ berat HIPS), Zinc Stearat $0,15 \mathrm{phr}$, dan selanjutnya diputar selama 10 menit. Hasil pencampuran tumbler dimasukkan ke ekstruder untuk diekstrusi dengan temperatur proses $200^{\circ} \mathrm{C}$ menghasilkan komposit HIPSPOFA dan dipeletisasi. Pencampuran dengan komposisi POFA $15 \%$ telah dicoba dan mengalami kesulitan dalam memperoleh campuran yang homogen. Komposit dicetak pada injection molding Yizumi UN90 untuk pembuatan spesimen properti sesuai dengan ISO. Spesimen didiamkan selama 24 jam di dalam desikator. Dilakukan pengujian sifat-sifat dan karakteristik masing-masing varian komposit sebanyak 3 kali dan hasilnya dirata-ratakan.

\section{Analisa Gugus Fungsi}

Lapis tipis HIPS dan komposit diuji pada alat Fourier Transform Infrared Spectroscope (FTIR) dan gugus fungsi diperkirakan dari puncak-puncak pada bilangan gelombang yang muncul. Resolusi spektrum yang dipilih dan jangkauan pemindaian adalah $400-4000 \mathrm{~cm}^{-1}$.

\section{Analisa Kadar Abu}

Kadar abu dihitung berdasarkan kehilangan massa dari suatu bahan dalam spesimen tes ketika dipanaskan. Mula-mula spesimen didalam cawan ditimbang kemudian dimasukkan ke dalam tungku atau furnace pada suhu $600{ }^{\circ} \mathrm{C}$ selama 30 menit.

Kadar abu $=\frac{\mathrm{A}-\mathrm{C}}{\mathrm{B}-\mathrm{C}} \times 100 \%$

Dimana:

$\mathrm{A}=$ massa cawan + sampel sesudah dibakar

$\mathrm{B}=$ massa cawan + sampel sebelum dibakar

$\mathrm{C}=$ massa cawan kosong

\section{Analisa Specific Gravity}

Specific gravity merupakan ukuran densitas suatu material dibandingkan dengan densitas air. Pengujian densitas dilakukan menggunakan alat electronic densimeter.

\section{Analisa Kekuatan Tarik}

Analisa kekuatan tarik (tensile strength) sesuai standard ISO 527. Spesimen komposit dicetak dengan menggunakan injection molding membentuk spesimen untuk pengujian kekuatan tarik (uji tarik). Pengujian kekuatan tarik dilakukan dengan Strograph W-2 terhadap tiap spesimen. Mesin dihidupkan dan spesimen akan tertarik ke atas spesimen diamati sampai putus, dicatat tegangan maksimum dan regangannya.

\section{Analisa Kekerasan}

Pengujian kekerasan dilakukan dengan metode Hardness Rockwell sesuai standar ISO
2039. Pengujian Rockwell bertujuan untuk menentukan suatu material dalam bentuk daya tahan material terhadap benda penguji yang ditekankan pada permukaan material uji tersebut. Pada penelitian ini digunakan metode uji kekerasan Rockwell dengan skala Rockwell R, yaitu:

Beban maksimal : $60 \mathrm{~kg}$

Tipe indenter : Bola baja $1 / 2$ inchi

\section{Analisa Kekuatan Bentur}

Pengujian kekuatan bentur dilakukan dengan metode charpy impact dengan standar ISO 179.

\section{Analisa Morfologi Permukaan (SEM)}

Sampel yang dianalisa yaitu abu pembakaran biomassa kelapa sawit nontreatment dan treatment, serta hasil uji bentur komposit HIPS berpengisi abu pembakaran biomassa kelapa sawit dengan ratio komposisi komposit HIPS-POFA tertinggi (90/10) dan terendah $(95 / 5)$ untuk melihat perubahan morfologi yang terjadi pada patahan komposit.

\section{Hasil dan Pembahasan}

\section{Gugus Fungsi (FTIR)}

Gambar 1 dan Gambar 2 menunjukkan hasil spektrum FTIR.

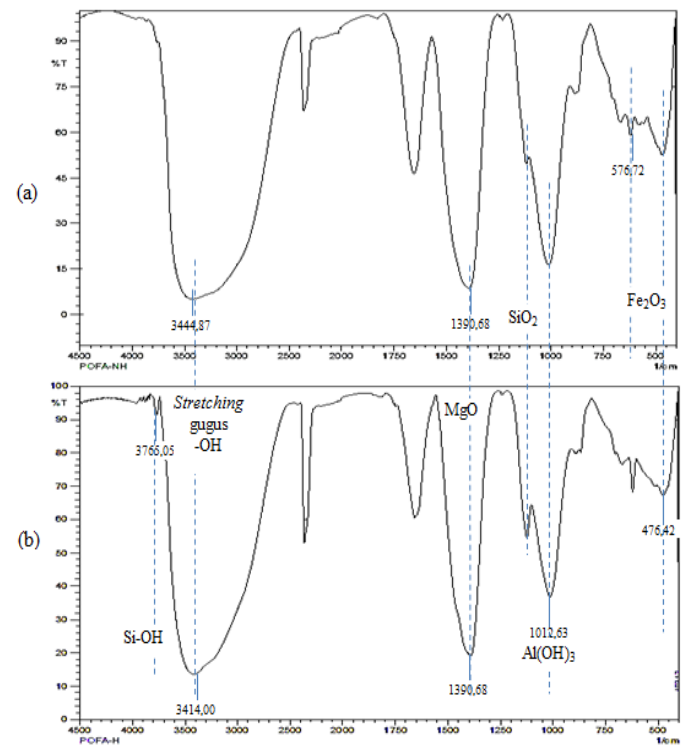

Gambar 1. Karakteristik FTIR POFA

(a) Nontreatment, (b) Treatment

Dari gambar 1 dapat dilihat bahwa perlakuan alkali kepada abu pembakaran biomassa kelapa sawit tidak banyak mengubah gugus fungsi dari abu pembakaran biomassa kelapa sawit itu sendiri. Gambar 4.1 (b) muncul sebuah puncak baru yaitu panjang gelombang $3765,05 \mathrm{~cm}^{-1}$ yang menunjukkan keberadaan dari gugus $\mathrm{Si}-\mathrm{OH}$ [7]. Munculnya gugus ini diduga karena abu pembakaran biomassa kelapa sawit 
telah mengalami modifikasi kimia (terbentuk ikatan $\mathrm{Si}-\mathrm{OH}$ dan atau kristal $\left.\mathrm{M}-\mathrm{Si}-\left(\mathrm{H}_{2} \mathrm{O}\right)_{\mathrm{n}}\right)$ / $\mathrm{M}=$ metal) setelah diberikan perlakuan alkali dengan larutan $\mathrm{NaOH}$. Modifikasi kimia dengan perlakuan alkali dilakukan untuk meningkatkan adhesi antara permukaan partikel dengan matriks polimer yang diharapkan berpotensi menghasilkan ikatan yang baik [1].

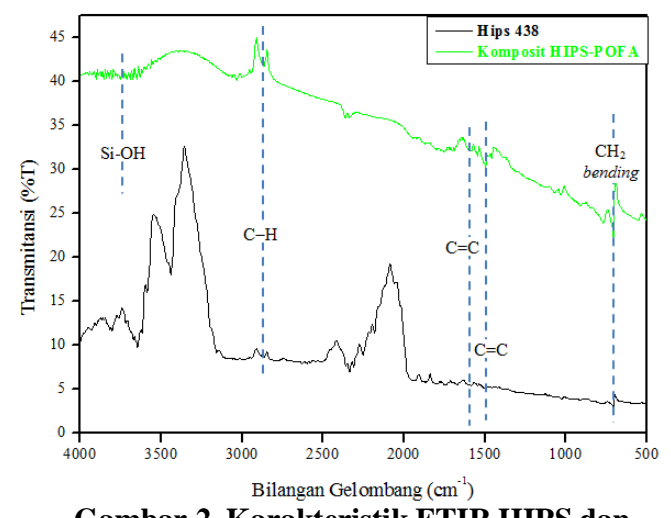

Gambar 2. Karakteristik FTIR HIPS dan Komposit HIPS-POFA terhidrasi

Dari gambar 2 terlihat bahwa penggabungan antara matriks dan bahan pengisi merupakan interaksi fisika (mekanik) saja.

\section{Specific Gravity Komposit HIPS}

Gambar 3 menunjukkan pengaruh penambahan POFA pada matriks HIPS terhadap spesific gravity komposit yang dihasilkan.

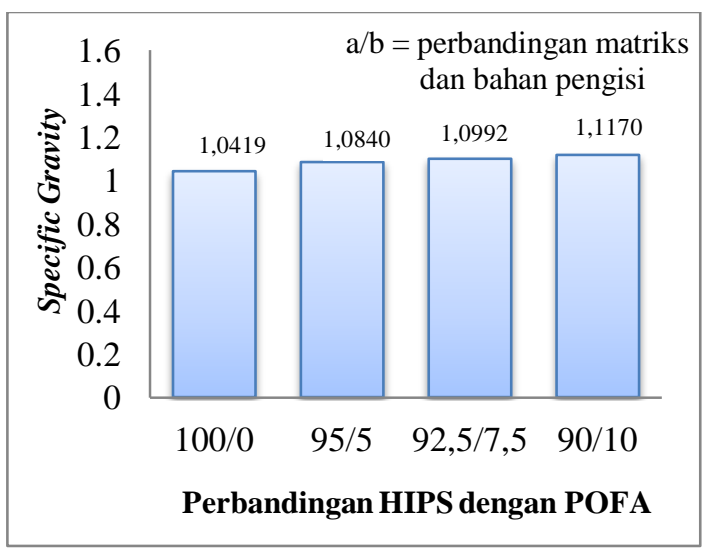

Gambar 3 Pengaruh Kandungan Bahan Pengisi Terhadap Spesific Gravity Komposit HIPS-POFA

Specific gravity merupakan ukuran densitas suatu material dibandingkan dengan densitas air. Pada Gambar 4.3 terjadi peningkatan specific gravity dengan meningkatnya kandungan bahan pengisi abu pembakaran biomassa kelapa sawit dan HIPS. Hal ini menunjukkan jumlah kekosongan atau porositas yang berkurang, sehingga kepadatan meningkat dan tentunya berat jenis menjadi meningkat [12].

\section{Kadar Abu Komposit HIPS}

Kadar abu dari komposit HIPS-POFA dapat dilihat dari Tabel 2. Hasil pengujian komposit menunjukkan bahwa kadar abu meningkat dengan meningkatnya kandungan bahan pengisi. Hal ini menunjukkan bahwa semakin bertambahnya bahan pengisi akan mengakibatkan komposit mengandung lebih banyak senyawa-senyawa yang tidak terdekomposisi. Abu pembakaran biomassa kelapa sawit mengandung sejumlah besar bahanbahan yang tidak terbakar, silika, dan alumunium [5]. Nilai kadar abu dari komposit dibawah nilai persentase POFA juga menunjukkan efisiensi pencampuran HIPS - POFA pada proses "tumbling" dan ektrusi belum sempurna.

Tabel 2. Kadar Abu Komposit HIPS - POFA

\begin{tabular}{|c|c|}
\hline Komposisi (HIPS/POFA) & Kadar Abu (\%) \\
\hline HIPS 100\% & 0,02 \\
$95 / 5$ & 4,81 \\
$92,5 / 7,5$ & 7,38 \\
$90 / 10$ & 9,04 \\
\hline
\end{tabular}

\section{Kekuatan Tarik Komposit HIPS}

Gambar 4 menunjukkan pengaruh penambahan POFA pada matriks HIPS terhadap kekuatan tarik komposit yang dihasilkan.

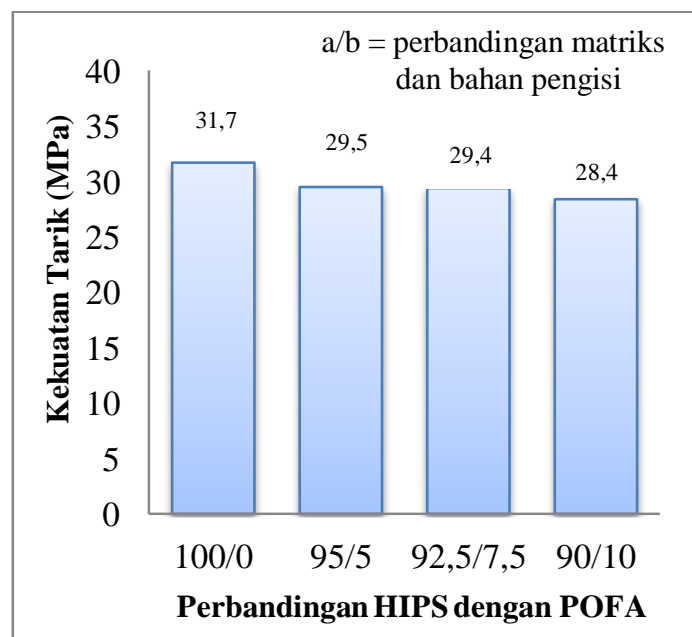

Gambar 4. Pengaruh Kandungan Bahan Pengisi Terhadap Kekuatan Tarik Komposit

Dari hasil uji tarik diperoleh bahwa kekuatan tarik antara HIPS murni dengan komposit HIPS tidak mengalami perubahan yang signifikan meskipun kekuatan tarik komposit cenderung menurun seiring dengan pertambahan komposisi POFA di dalam komposit. Penambahan pengisi mengakibatkan komposit kehilangan sifat elastisnya, dengan kata lain, material komposit yang dihasilkan bersifat lebih keras (rigid) [4].

Sifat Pemanjangan (Elongation at Break) Pada Saat Putus Komposit HIPS

Gambar 5 menunjukkan pengaruh penambahan POFA pada matriks HIPS terhadap 
sifat pemanjangan (elongation break) pada saat putus.

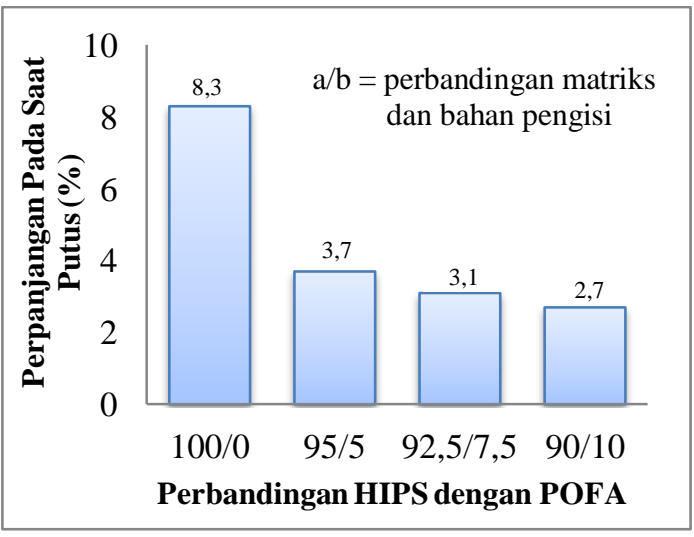

Gambar 5. Pengaruh Kandungan Bahan Pengisi

Terhadap Sifat Pemanjangan (Elongation Break)

Pada Saat Putus Komposit

Hasil pengujian komposit menunjukkan bahwa pemanjangan pada saat putus menurun dengan meningkatnya kandungan bahan pengisi abu pembakaran biomassa kelapa sawit. Sifat elastisitas dari komposit diindikasikan oleh penambahan panjang saat putus (elongation at break). Secara umum, elastisitas material yang tinggi menandakan tingginya nilai dari elongation at break. Penambahan pengisi mengakibatkan komposit kehilangan sifat elastisnya, dengan kata lain, material komposit yang dihasilkan lebih rapuh (brittle) dan keras (rigid). Kemampuan komposit HIPS untuk berdeformasi menjadi semakin terbatas seiring dengan mengingkatnya kandungan pengisi di dalam komposit HIPS [4].

\section{Kekuatan Bentur Komposit HIPS}

Gambar 6 menunjukkan pengaruh penambahan POFA pada matriks HIPS terhadap kekuatan bentur komposit.

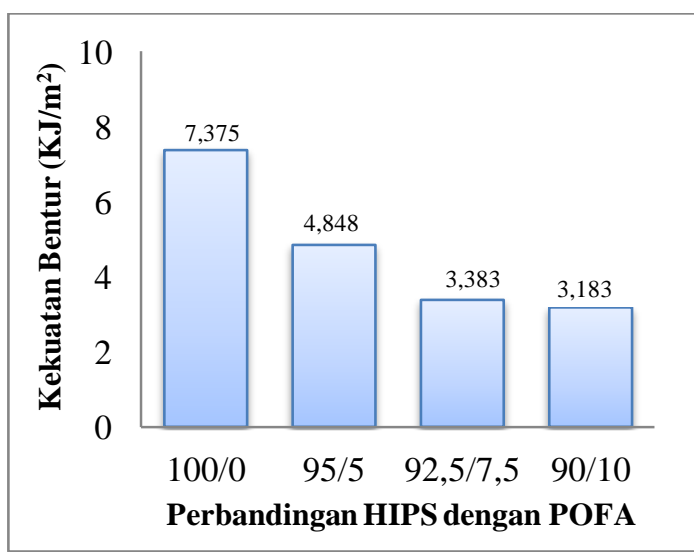

Gambar 6. Pengaruh Kandungan Bahan Pengisi Terhadap Kekuatan Bentur Komposit

Penurunan kekuatan bentur komposit disebabkan interaksi antar massa matriks telah diisolir oleh bahan pengisi POFA tergantikan dengan interaksi HIPS - POFA secara merata. Sementara polistirena (PS) yang bersifat kristalin ditingkatkan karakteristik fleksibilitasnya dengan penambahan karet agar diperoleh PS dengan karakteristik "High Impact". Dalam hal ini diduga interaksi PS kristalin dengan karet tergantikan oleh PS-POFA hidrat- Karet. Hal ini menyebabkan interaksi antar matriks tidak lagi maksimal. Ikatan permukaan yang lemah juga dapat menurunkan kekuatan bentur bahan komposit tersebut. Penambahan pengisi mengakibatkan komposit yang dihasilkan menjadi lebih rapuh (brittle) [4] sehingga kemampuan komposit untuk menahan beban yang mendadak semakin menurun.

\section{Kekerasan Komposit HIPS}

Gambar 7 menunjukkan pengaruh penambahan POFA pada matriks HIPS terhadap kekerasan (hardness rockwell) komposit.

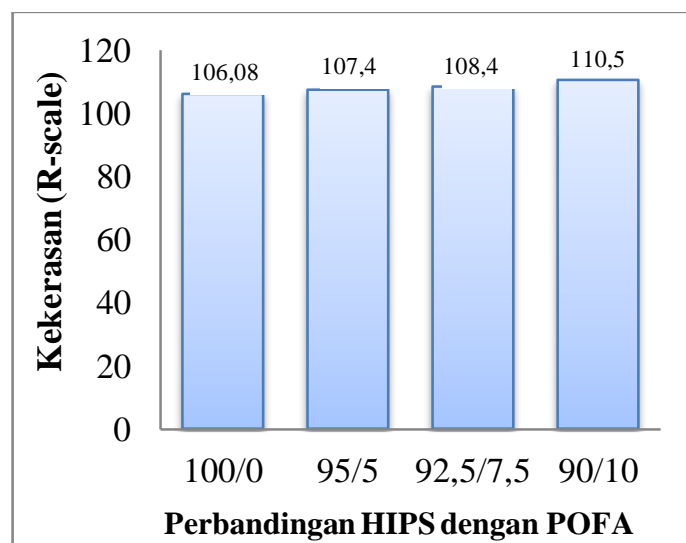

Gambar 7. Pengaruh Kandungan Bahan Pengisi Terhadap Kekerasan (Hardness) Komposit

Meningkatnya kandungan pengisi pada komposit mengakibatkan meningkatnya kekerasan komposit HIPS berpengisi abu pembakaran biomassa kelapa sawit. Karena pada abu pembakaran biomassa kelapa sawit terdapat kandungan unsur logam yang dapat mempengaruhi kekerasan komposit. Sehingga mampu memperkuat struktur material pada bahan komposit dan akhirnya dapat meningkatkan nilai kekerasannya. Kekerasan merupakan sifat mekanik yang menunjukkan ketahanan terhadap deformasi platis atau permanen. Sifat kekerasan juga dipengaruhi oleh faktor porositas bahan tersebut, karena porositas berkurang membuat tingkat kepadatan bahan dapat meningkatkan kekerasan. Nilai porositas yang rendah menunjukkan bahwa bahan tersebut memiliki rongga- rongga lebih kecil, sehingga memperkuat struktur material pada bahan [11].

Scanning Electron Microscopy (SEM) Morfologi permukaan abu pembakaran 
biomassa kelapa sawit telah dianalisa menggunakan Scanning Electron Microscopy (SEM) seperti pada gambar 8 di bawah ini.

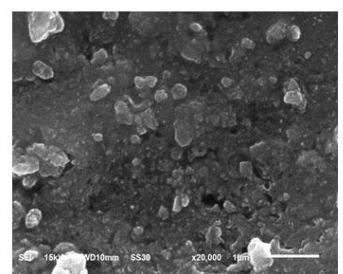

(a)

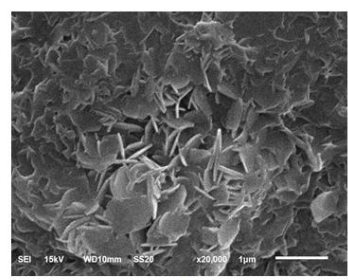

(b)
Gambar 8. Hasil SEM POFA Dengan Perbesaran 20.000 kali (a) POFA Nontreatment (b) POFA Treatment

Dari Gambar 8 (a) terlihat bahwa struktur permukaan abu yang belum mendapat perlakuan alkali masih amorfous atau berbentuk seperti gelas. Sedangkan Gambar 8 (b) terlihat bahwa struktur abu sudah mengkristal dan berbentuk seperti lempengan. Hal ini dikarenakan telah terjadinya reaksi hidrasi pada POFA sehingga mengubah struktur POFA yang tadinya berbentuk amorf menjadi berbentuk lempengan. Perlakuan POFA dengan $\mathrm{NaOH}$ mengakibatkan oksida-oksida logam dan silika oksida melakukan reaksi hidrasi sehingga terbentuk air hidrat yang stabil. Air hidrat ini juga merubah morfologi POFA yang amorf menjadi kristal.

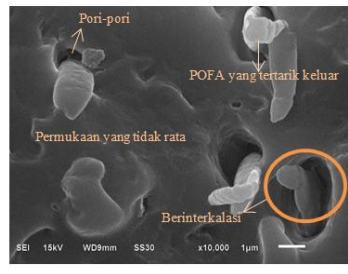

(a)

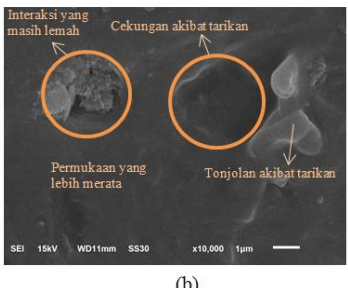

(b)

Gambar 9. Hasil SEM Komposit HIPS-POFA (a) Ratio 95/5 (b) Ratio 90/10 Dengan Perbesaran 10000 kali

Gambar 9 (a) dan Gambar 9 (b) menunjukkan ikatan antara matriks dan pengisi tidak semuanya sempurna. Ada yang dapat terikat dan ada yang tidak dapat terikat. Hal ini diperlihatkan dari cekungan yang terbentuk. Cekungan yang terbentuk diduga dari tertariknya bongkahan POFA dari matriks ketika terjadi patahan. Hal ini juga dapat mengindikasikan bahwa reaksi hidrasi akibat perlakuan alkali pada POFA, tidak homogen atau tidak merata pada keseluruhan POFA. Selain itu, dapat dilihat bahwa penambahan pengisi ke dalam matriks dapat mengurangi jumlah fraksi kosong (void) dan meningkatkan kerapatan serta kepadatan komposit sehingga meningkatkan kekerasan dari komposit.

\section{Kesimpulan}

Dari hasil analisa FTIR terhadap POFA, tidak terjadi perubahan gugus yang signifikan. Pembentukan komposit dilakukan secara reaksi fisika (mekanik) saja. Kadar abu, specific gravity, dan kekerasan komposit mengalami peningkatan seiring dengan bertambahnya komposisi pengisi di dalam komposit. Kekuatan tarik dan kekuatan bentur komposit mengalami penurunan, serta komposit kehilangan sifat elastisitasnya seiring dengan penambahan komposisi POFA di dalam komposit. POFA yang ditreatment cukup berpotensi untuk dijadikan filler pada HIPS dan atau membentuk komposit untuk memperoleh sifat-sifat fisika dan mekanik tertentu.

\section{Daftar Pustaka}

[1] Danil Tarmizi, Kartini Noor Hafni, A. Haris Simamora. Jurnal Teknik Kimia USU, vol III, No 1, 2014.

[2] David Bahrin, Nukman, Yuri Dariansyah. Prosiding Seminar Nasional AvoER ke-3. Palembang, 26-27 Oktober 2011. ISBN:979-587-395-4, p. 110-115.

[3] M. Indra Lamora, Program Sarjana Fakultas Teknik, Universitas Sumatera Utara, Medan, 2008.

[4] M.S. Ibrahim, S.M Sapuan, A.A Faieza. Journal of Mechanical Engineering and Sciences (JMES), vol. II (Juni, 2012), p. 133-147.

[5] Nurdeen M. Altwair, Megat Azmi Megat Johari, Syed Fuad Saiyid Hashim. International Journal of Civil \& Environmental Engineering IJCEE-IJENS, vol XI, no: 05, p. 100-107.

[6] Omnexus. www.omnexus.specialchem. com. 2012, diakses pada 9 Mei 2014

[7] Philip J. Launer. Laboratory For Materials, Inc., New York, 1987, p.100-103.

[8] Rahmani Kadarningsih, Komang Arya Utama, Fakultas Teknik. Universitas Gorontalo, Gorontalo, 2012.

[9] Siti Khairunizar. Program Sarjana Fakultas MIPA Universitas Sumatera Utara, Medan, 2009.

[10] Spartech Corporation, www.spartech.com 2012, diakses pada 13 Januari 2014

[11] Sunardi, dkk, Jurnal Teknik Mesin UNTIRTA, Volume 1, Nomor 1, April 2015, p. 90-102.

[12] Toto Rusianto, Jurnal Teknologi, Volume 2, Nomor 1, Juni 2009, p. 89-95. 